\title{
THE INFLUENCE OF TRUST, COMMITMENT AND CONFLICT-HANDLING ON CUSTOMER LOYALTY: A PARALLEL INVESTIGATION
}

\author{
Mornay Roberts-Lombard* \\ University of Johannesburg \\ mornayrl@uj.ac.za
}

\author{
Lauren Strachan\# \\ University of Johannesburg \\ Strachan@uj.ac.za
}

\author{
Leon du Plessis+ \\ University of Johannesburg \\ Iduplessis@pps.co.za
}

April 2012

\begin{abstract}
The primary objective of this article is to compare the influence of trust, commitment, and conflicthandling on customer loyalty through the intervening role of Customer Relationship Management (CRM) in the life and non-life insurance sector of South Africa. Primary data was gathered using a questionnaire. The sample consisted of 254 life insurance and 400 non-life insurance customers in South Africa. Multiple regression analysis was used to test the hypotheses. For the life insurance component of the study, trust, commitment and conflict-handling exerted a statistically significant positive influence on CRM. CRM also positively influenced customer loyalty. For the non-life insurance component of the study, no significant relationship exists between trust and CRM. A significant positive relationship does exist between conflict-handling and CRM, while a significant negative relationship exists between commitment and CRM. Therefore, life and non-life insurance providers should retain and develop loyal customers by being trustworthy (giving and keeping promises, providing quality services and illustrating a respect for customers), committed (enhanced segmentation of the customer base and increased customer surveys), and, lastly, by resolving conflicts in a timely and acceptable manner, limiting the difficulties and disappointment experienced by the customer.
\end{abstract}

\section{Keywords}

Trust, Commitment, Conflict-handling, Customer Relationship Management (CRM), Customer loyalty, Life insurance industry, Non-life insurance industry.

*Prof Mornay Roberts-Lombard is professor at the Department of Marketing Management, University of Johannesburg, South Africa.

\#Lauren Strachan and +Leon du Plessis are postgraduate students at the Department of Marketing Management, University of Johannesburg, South Africa. 


\section{INTRODUCTION}

The insurance industry in South Africa is revolutionising the Financial Services Sector. The life insurance industry, also referred to as the long-term insurance industry, contributes to the South African economy in two ways. The savings of customers are invested into capital projects to develop the country, and the income of households is protected against loss of income related to the untimely death of the breadwinner. South African families are underinsured by R10 billion (Hugo \& Zondagh, 2007). The South African insurance market generated total gross written premiums of $\$ 24.5$ billion in 2010 , representing a compound annual growth rate (CAGR) of $8.2 \%$ for the period spanning 2006-2010. The life insurance segment was the market's most lucrative in 2010 , generating gross written premiums of $\$ 14.4$ billion, equivalent to $58.7 \%$ of the market's overall value. The non-life segment (also referred to as short-term insurance) generated the remaining $41.3 \%$. The performance of the insurance market (both the life and non-life segments) is forecast to accelerate by an anticipated CAGR of $10.8 \%$ for the five-year period (2007-2012), which is expected to drive the market up to a value of $\$ 42.3$ billion (Datamonitor, 2011). However, economic activity in South Africa slowed down in the last quarter of 2010 and the first quarter of 2011 (Life Offices Association, 2011). With the slowdown in economic activity, both long-term and short-term insurance providers have to focus on retaining their current customers. CRM can therefore be used to improve customer loyalty in these two market segments (Leverin \& Liljander, 2006).

The crucial aim of many successful service organisations is to target, gain and retain beneficial customers. These organisations attempt to create loyal customers. Loyal customers raise profitability for an organisation over time. Consequently, these organisations try to use tactics in order to encourage their beneficial customers to become loyal customers (Halimi, Chavosh \& Choshali, 2011). Customer loyalty is therefore considered a vital link and aspiration to organisational success, profit and business performance. The consumers who show the greatest levels of loyalty towards the product or service activity tend to repurchase more often and spend more money (Jumaev, Kumar \& Hanaysha, 2012). Strachan (2010) and Du Plessis (2010) state that CRM can assist insurance organisations in building long-term beneficial relationships with customers, which has a direct influence on the value proposition to customers, and the competitive position of the organisation in the market. This will lead to customer loyalty and increased profits for the organisation.

This article includes a literature review of CRM and its antecedents, and an explanation of the problem that was investigated. The research objectives, hypotheses and methodology are then discussed. Thereafter, the empirical results are discussed, and this is followed by a discussion of the management implications and recommendations.

\section{LITERATURE REVIEW}

\subsection{Trust}

Before a relationship can exist, both parties must mutually perceive that the relationship exists. Relationships therefore comprise a series of transactions which build an awareness regarding a shared relationship through trust and commitment. Higher levels of trust and commitment in turn are associated with higher levels of customer retention, and this leads to increased organisational profitability (Read, 2009; Morgan \& Hunt, 1994). Trust is therefore a primary 
determinant of relationship commitment (Cacares \& Paparoidamis, 2007). Benamati, Fuller, Serva and Baroudi (2009) state that "trust is the willingness of a party to be vulnerable to or dependent on the actions of another party in situations of risk". The trusting relationship between a customer and an organisation is associated with overall positive outcomes, and trust in the organisation should increase the benefit derived from transacting with the organisation (Botha \& van Rensburg, 2010). Nguyen and Mutum (2012) concur by stating that if an organisation delivers on its promises, it becomes trusted by the client. The customer will then be more likely to utilise the organisation's services again, as the customer knows what he/she can expect from the organisation. It is therefore hypothesised that:

$\mathrm{HO}^{1 \mathrm{a}}$ : There is no relationship between the perceived trustworthiness of a life insurance organisation and CRM at this organisation in South Africa.

$\mathrm{HA}^{\mathrm{la}}$ : There is a relationship between the perceived trustworthiness of a life insurance organisation and CRM at this organisation in South Africa.

$\mathrm{HO}^{1 \mathrm{~b}}$ : There is no relationship between the perceived trustworthiness of non-life insurance organisations and CRM at these organisations in South Africa.

$\mathrm{HA}^{\mathrm{lb}}$ : There is a relationship between the perceived trustworthiness of non-life insurance organisations and CRM at these organisations in South Africa.

\subsection{Commitment}

Ndubisi and Wah (2005) state that, like trust, commitment is one of the important variables for understanding the strength of a marketing relationship. It is a useful construct for measuring the likelihood of customer loyalty. Nguyen and Mutum (2012) are of the opinion that commitment is the most common dependent variable used in a buyer-seller relationship and an essential ingredient for successful, long-term relationships. Commitment arises from trust, shared values and the belief that partners will be difficult to replace. Commitment motivates partners to co-operate in order to preserve the relationship investments (Morgan \& Hunt, 1994). Commitment is an "intention to continue a course of action or an activity or a desire to maintain a relationship" (Amin, Almani, Pournaserani \& Mousavian, 2011). It furthermore implies that partners forgo short-term alternatives in favour of long-term benefits associated with current partners. Customers will make commitments only to trustworthy partners, because commitment entails vulnerability and leaves them open to opportunism (Read, 2009). It is therefore hypothesised that:

$\mathrm{HO}^{2 \mathrm{a}}$ : There is no relationship between the perceived commitment of a life insurance organisation and CRM at this organisation in South Africa.

$\mathrm{HA}^{2 \mathrm{a}}$ : There is a relationship between the perceived commitment of a life insurance organisation and CRM at this organisation in South Africa.

$\mathrm{HO}^{2 \mathrm{~b}}$ : There is no relationship between the perceived commitment of non-life insurance organisations and CRM at these organisations in South Africa. 
$\mathrm{HA}^{2 \mathrm{~b}}$ : There is a relationship between the perceived commitment of non-life insurance organisations and CRM at these organisations in South Africa.

\subsection{Conflict-handling}

Conflict refers to the level of disagreement between both parties acting in an exchange which can be perceived in a relationship. It reduces the possibility of creating and maintaining a longterm relationship (Amin et. al, 2011). It is the organisation's ability to minimise the negative consequences of manifested and potential conflicts. Conflict-handling includes the organisation's ability to avoid potential conflicts, to solve manifested conflicts before they create problems, and to discuss solutions when problems arise. How conflicts are handled will influence customer loyalty directly (Ndubisi, 2007). The degree to which the different parties in the relationship engage in conflict-handling processes will depend on their prior satisfaction with the relationship, the magnitude of the investment in the relationship, and the alternatives that the parties have (Sauers, 2008). Organisations that encourage disappointed customers to complain and empower employees to remedy the situation at the time and place of its occurrence have been shown to achieve higher revenues and greater profits (Kotler \& Keller, 2006). It is therefore hypothesised that:

$\mathrm{HO}^{3 \mathrm{a}}$ : There is no relationship between the perceived conflict-handling by a life insurance organisation and CRM at this organisation in South Africa.

$\mathrm{HA}^{3 \mathrm{a}}$ : There is a relationship between the perceived conflict-handling by a life insurance organisation and CRM at this organisation in South Africa.

$\mathrm{HO}^{3 \mathrm{~b}}$ : There is no relationship between the perceived conflict-handling by non-life insurance organisations and CRM at these organisations in South Africa.

$\mathrm{HA}^{3 \mathrm{~b}}$ : There is a relationship between the perceived conflict-handling by non-life insurance organisations and CRM at these organisations in South Africa.

\subsection{Customer Relationship Management (CRM) and customer loyalty}

Previous research on CRM suggested that organisations implement CRM to strengthen their ability to communicate with customers, provide them with feedback in a timeous manner, analyse customer information and customise offerings. Therefore, the implementation of CRM strategies takes place to enhance the smooth dissemination of customer information throughout the organisation, the purpose being to enhance the quality of decision-making (Krasnikov, Jayachandran \& Kumar, 2009). CRM is a strategic approach that is concerned with creating improved shareholder value through the development of appropriate relationships with key customers and customer segments. CRM unites the potential of relationship marketing strategies and IT to create profitable, long-term relationships with customers and other key stakeholders (Payne \& Frow, 2005). CRM has been characterised as one of the tools to providing continuous and long-term relationships with customers and offering continuous and good services to them. There are four primary goals of CRM, namely to encourage potential customers and other customers to doing the first purchase from the corporation, encouraging people who have done a first purchase previously also to do a follow-up purchase, converting temporary and random customers to loyal ones, and offering high-quality services to loyal customers in order 
to increase corporations' sales (Mousavian, Moaf, Jelodarloo, Pournemat, Tajalli, Damirchi \& Seighalani, 2011).

CRM is important for service organisations. If organisations desire a good relationship with customers, they must ensure that their management and staff are trustworthy and show a strong commitment to service (Tynan \& McKechnie, 2009). Trust and commitment are key elements for retaining customers (Du Plessis et al., 2005). Unless there is a minimum level of trust between the parties in the relationship, it is unlikely that a relationship will be maintained. When trust breaks down in a relationship, the relationship is likely to dissolve. Trust can be established only after numerous interactions have taken place between the parties. Trust between the parties must be developed and it must be seen as an investment in the relationship building that has a long-term benefit for both parties. Trust emerges as parties share experiences and interpret and assess each other's motives. As the parties learn more about one another, risk and doubt are reduced (Kim, Kim, Kim, Kim \& Kang, 2008). Similar to trust, commitment appears to be one of the most important variables in understanding relationships, and it is a useful construct for measuring the likelihood of customer loyalty, as well as for predicting future purchase frequency (Wong \& Sohal, 2002). How conflict is handled between the organisation and the customer will either ensure loyalty, or the customer will leave the organisation and go to a competitor (Ndubisi \& Wah, 2005). Long-term relationships with customers can successfully be created, reinforced and retained by building the customers' trust in an organisation over time, demonstrating a commitment by the organisation to service and handle conflicts between the organisation and the customers effectively (Ndubisi, 2007).

The rationale behind CRM is that it improves organsational performance by enhancing customer satisfaction and driving up customer loyalty (Lian, Chen \& Wang, 2008). Customer satisfaction increases because the insight into customers allows organisations to understand them better, and through this organisations create improved customer value propositions. As customer satisfaction rises, so does customer repurchase intention. This then influences the actual purchasing behaviour, which significantly impacts organisational performance (Angelis, Pinheiro de Lima \& Siraliova, 2010). Therefore, organisations must track customer loyalty as a more accurate measure of how they compare to competitors, and this will shift the focus from customer acquisition to customer retention (Baran, Galka \& Strunk, 2008).

It is therefore hypothesised that:

$\mathrm{HO}^{4 a}$ : here is no relationship between CRM and customer loyalty at a life insurance organisation in South Africa.

$\mathrm{HA}^{4 \mathrm{a}}$ : There is a relationship between CRM and customer loyalty at a life insurance organisation in South Africa.

$\mathrm{HO}^{4 \mathrm{~b}}$ : There is no relationship between CRM and customer loyalty at non-life insurance organisations in South Africa.

$H_{A}^{4 b}$ : There is a relationship between CRM and customer loyalty at non-life insurance organisations in South Africa. 


\subsection{The importance of the three antecedents of CRM to customer loyalty - A theoretical model proposition}

Over the past two decades, organisations have become more aware of the importance of customer loyalty, and have concluded that keeping customers is more important than recruiting new ones. It is for this reason that the continuous monitoring of the organisation's relationship with its customers is of vital importance. To supply a customer with the goods and services wanted, an accurate understanding of customer needs must be achieved (Mousavian et al., 2011). The literature reveals that trust, commitment and conflict handling form part of CRM. Before customers will transact with an organisation, they must trust the organisation. Trust is based on repeated, reliable interactions and following through on expected behaviours (Sauers, 2008). If an organisation succeeds in avoiding or resolving conflicts with customers before they become problems, this will have a positive influence on customer loyalty (Ndubisi \& Wah, 2005). This will lead to commitment, which encompasses the willingness to work and stay in the relationship indefinitely. To enhance the long-term profitability of customers, organisations must interact with individual customers to improve their knowledge of the individual customer's needs and to build a stronger relationship (Theron \& Terblanche, 2009). There can only be a relationship with a customer if the customer chooses the relationship, as not all customers want relationships with organisations (Kotler \& Keller, 2006). An organisation will therefore have loyal customers only if the organisation starts managing customers professionally. Retaining profitable customers has become increasingly difficult in a competitive environment where competitors specialise in offering attractive services and prices to customers (Leverin \& Liljander, 2006).

The CRM literature reviewed revealed three key virtues of customer management, namely trust (Jumaev et al., 2012; Alhabeeb, 2007; Morgan \& Hunt, 1994; Moorman, Deshpandè \& Zaltman, 1993), commitment (Adoyo, Ondoro, Ojeroa, Abong'o, Aila \& Jeremia, 2012; Kaur, Sharma \& Mahajan, 2011; Ndubisi, 2004; Morgan \& Hunt, 1994), and conflict-handling (Chan, 2004; Dwyer, Schurr \& Oh, 1987). Morgan and Hunt (1994) stipulate that trust and commitment are central to relationship marketing because they encourage marketers to work at preserving relationship investments by cooperating with exchange partners, resist attractive short-term alternatives in favour of the expected long-term benefits of staying with existing partners, and view potentially high-risk actions as being prudent because of the belief that their partners will not act opportunistically. Jumaev et al. (2012) state that trust is an important construct in relational exchange, because relationships characterised by trust are so highly valued that parties will desire to commit themselves to such relationships. Morgan and Hunt (1994) support this argument by stating that trust has been posited as a major determinant of relationship commitment. Kaur, Sharma and Mahajan (2012) also established that the creation of trust in the mind of the customer is important for organisations, because from previous studies it was concluded that trust along with commitment is an important antecedent of loyalty. In order to increase the levels of trust, organisations must focus on keeping promises made to their customers, and consistently have their best interests at heart. In addition, Ndubisi and Wah (2005) argue that conflict-handling is an additional virtue that underpins the value of CRM in retaining customers over the long-term. They stipulate that this virtue has not been explored to the same extent as trust and commitment, but is as important in the establishment and maintenance of long-term relationships with customers.

From the background, problem statement and literature discussion, it can be concluded that the relationship between trust, commitment, conflict handling, CRM and customer loyalty needs to 
be investigated, as the relationships have remained unexplored. FIGURE 1 reflects the hypothesis and the relationship between the independent variable, the intervening variable and the dependent variable. These relationships are important, as they can lead to increased customer loyalty for the organisation.

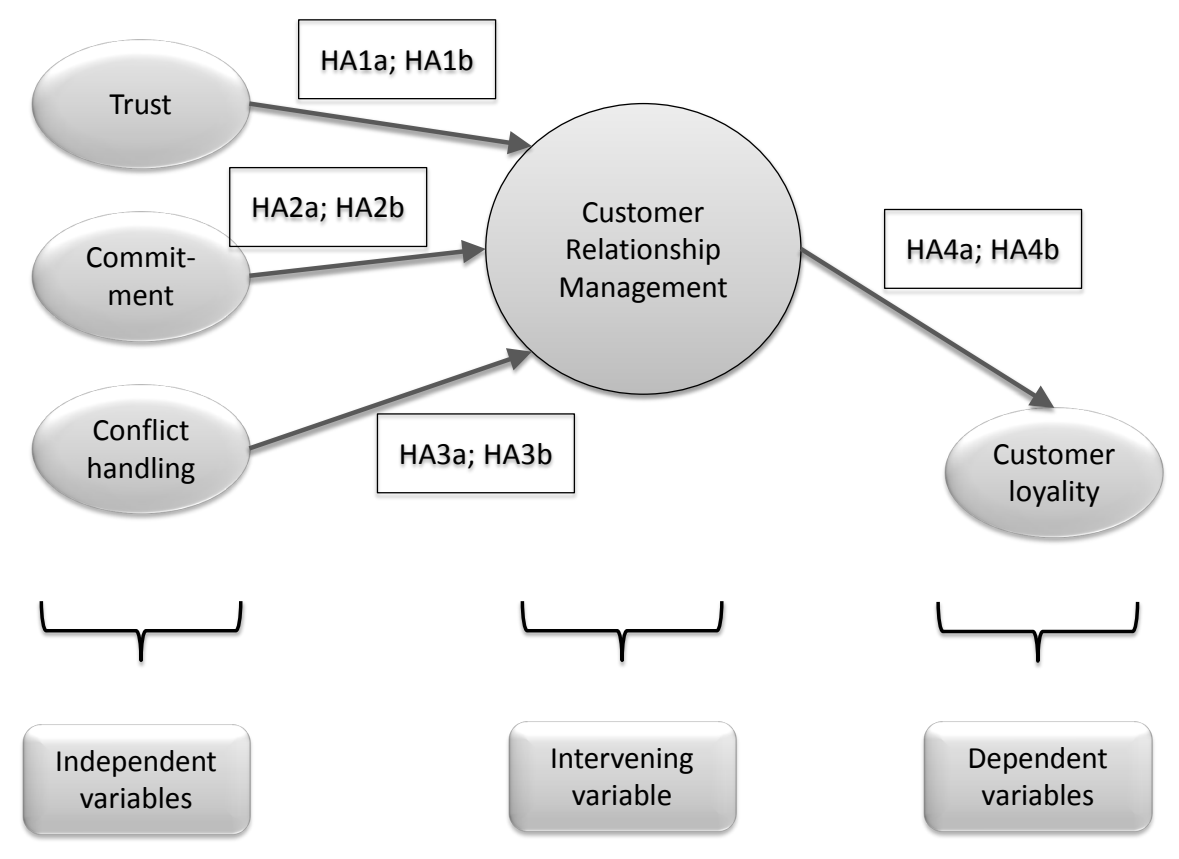

\section{FIGURE 1: Conceptual model - Life and non-life insurance industry}

\section{Source: Researcher's construct}

\section{PROBLEM INVESTIGATED}

Statistics released by the Life Offices Association (2011) indicated that in the second half of 2010 surrenders of policies increased, and lapsed premiums also increased by $19.5 \%$ as compared to the previous half-year, and by $32.5 \%$ compared to the corresponding period in 2009. This is primarily due to the fact that individuals are living on a restricted budget and do not consider insurance (both life and non-life) to be a priority cost. To retain existing customers in the current economic climate where customers are lapsing or surrendering their insurance policies (both life and non-life) because of the uncertain economic future, insurance organisations will have to understand how trust, commitment, and conflict-handling through the application of CRM can contribute to customer loyalty. There is a lack of information on the relationship between trust, commitment, conflict-handling, CRM and customer loyalty within the life and non-life insurance industry in South Africa. Therefore, these relationships need to be explored, as they could provide a means to improve customer loyalty within the insurance industry in South Africa. 


\section{RESEARCH OBJECTIVES}

Emanating from the research problem, the objectives of the survey were the following:

- To investigate whether trust, commitment, and conflict-handling influence CRM in the life and non-life insurance industry in South Africa.

- To investigate the intervening role of CRM on the effect of trust, commitment, and conflicthandling on customer loyalty in the life and non-life insurance industry in South Africa.

\section{RESEARCH METHODOLOGY}

\subsection{Sample and data collection}

The target population for this study included the entire individual, natural person customers of a life insurer and two non-life insurers who visited customer walk-in-centres in Johannesburg, Pretoria, Cape Town, Durban and Port Elizabeth. The study made use of a descriptive research design, which is quantitative in nature. The probability sampling method was chosen for this study, because in this method each element of the population, namely all the visitors to the Customer Walk-in-Centres in Johannesburg, Pretoria, Cape Town and Durban, had a known, nonzero chance of being included in the sample. Sampling was not done at the discretion of the researcher, as would have been the case had non-probability sampling been employed. Malhotra (2007) states that with non-probability sampling, the probability of selection of respondents is unknown, and the researcher cannot be certain that the sample will be representative of the population.

Stratified sampling was applied to the study, since the sampling frame of the study was divided into subgroups and strata, and the sampling process was performed separately on each stratum. Stratified samples are statistically the most efficient and they allow for the investigation of the characteristics of the interest for particular subgroups within the population (Churchill \& Lacobucci, 2005). The sample size of this study included 254 life insurance and 400 non-life insurance customers.

\subsection{Measuring instrument}

The measuring instrument used for the study was based on both self-developed items and items from measuring instruments used in previous research by Ndubisi and Wah (2005). Suitable scale items considered reliable and valid were also obtained from the Marketing Scales Handbook (Bruner, Hensel \& James, 2005) to measure trust and commitment towards the life and non-life insurance organisations in the study. Scale items were adapted for use in the research instrument to measure the perceptions of customers regarding their loyalty towards these organisations. The research instrument was pre-tested in a pilot study involving fifteen customers of the organisations in the study who visited the Customer Walk-in-Centre in Johannesburg. The research instrument consisted of two sections. Part A was in the format of a seven-point Likert-type scale. This part measured the items of trust, commitment, and conflicthandling, and the perceptions of customers on the CRM strategies of the insurance organisations on customer loyalty. Part B gathered demographic information from the respondents. Part A was in the form of fixed-alternative questions, which are questions where the respondents are given specific limited-alternative responses and asked to choose the one closest to their viewpoints. 
Part B contained fixed-alternative questions and open-ended response questions which the respondents answered in their own words.

\section{DATA ENTRY, EDITING, CODING AND ANALYSIS}

The data on the questionnaires was coded, entered and edited for analysis using the Statistical Package for Social Sciences (SPSS version 18). The data analysis firstly involved examining the frequency distribution of the results for each of the scale items included so as to determine whether the data was normally distributed. The normality of the distribution of results of each scale item was ascertained in order to determine whether parametric or non-parametric tests should be used to test the hypotheses formulated for the study. The distribution of results can be considered normal if it exhibits a skewness of less than an absolute value of 2.00 , and a kurtosis of the distribution of less than 7.00 (West, Finch \& Curran, 1995). All scale items used fall within these parameters. Based on this fact and the fact that the sample size is relatively large $(n=654)$, parametric tests were considered suitable for hypothesis testing. Multiple regression analysis was performed to assess the relationship between trust, commitment, conflict-handling and CRM as well as the relationship between CRM and customer loyalty.

\subsection{Reliability}

The internal consistency reliability test compares different samples of the items being used to measure a phenomenon, during the same time period. This can be done by means of a split-half reliability test, also known as the coefficient alpha or Cronbach's alpha, and results exceeding 0.60 will reflect the lower level of acceptability (Ndubisi \& Wah, 2005). The reliability statistics for the questionnaire are presented in TABLEl.

\section{TABLE 1: Reliability statistics}

\begin{tabular}{|c|c|}
\hline & CRONBACH'S ALPHA \\
\hline Trust & 0.906 \\
\hline Commitment & 0.890 \\
\hline Conflict-handling & 0.882 \\
\hline CRM & 0.941 \\
\hline Customer loyalty & 0.918 \\
\hline
\end{tabular}

Source: Researcher's construct

It is evident in TABLE 1 that Cronbach's alpha for all the constructs is above the lower limit of acceptability, 0.60 . This confirms that the measurement set used in the study was reliable. 


\subsection{Construct validity}

Construct validity was confirmed by relating scale items taken from previous research and adapting them for use in this study. Validity was furthermore confirmed by conducting the Bartlett's test of sphericity. Through this test, all the items on the research instrument illustrating a significant $<0.05$ rating indicated the validity of the research instrument (Madiba, 2009). TABLE 2 indicates the result of the Bartlett's test of sphericity.

TABLE 2: Barlett's test for item validity

\begin{tabular}{llc}
\hline & Approx. Chi-Square & 5244.167 \\
BARTLETT'S TEST & Df & 651 \\
& Sig. & 0.000 \\
\hline
\end{tabular}

Source: Developed for the study

According to TABLE 2, the research instrument is valid, since the significant level is 0.000 .

\section{FINDINGS}

\subsection{The influence of trust, commitment, and conflict-handling on CRM}

Multiple regression analysis was performed to assess the relationship between trust, commitment and conflict-handling on CRM. The results are reflected in TABLE 2 for the life insurance industry, and TABLE 3 for the non-life component.

\subsubsection{Life insurance industry}

In terms of the life segment of the insurance industry, TABLE 3 indicates that trust, commitment and conflict-handling exerted a statistically significant positive influence on CRM. The reason for this is that if trust has been established between a customer and the organisation and complaints have been managed in a manner that enhances the customer's level of satisfaction, thereby improving the willingness of the customer to commit to the relationship, the need for communication with the organisation is reduced. The researcher relied on a $95 \%$ level of confidence; therefore a p-value of less than or equal to 0.05 implied that it is highly unlikely that the results are due to chance only according to the Independent Sample t-test. This implied that the null hypotheses are rejected and the alternative hypotheses are accepted. The relationship between trust and CRM is significant at $p=0.034$, the relationship between commitment and CRM is significant at $p=0.000$, and the relationship between conflict-handling and CRM is significant at $p=0.000$. The Beta values range between 0.148 and 0.517 , with conflict-handling (0.517) having the largest influence on CRM and trust (0.148) having the lowest influence.

Alternative hypotheses $H A^{2 a}, H A^{2 a}$ and $H A^{3 a}$ are therefore accepted. 
TABLE 3: Influence of trust, commitment and conflict-handling on CRM

\begin{tabular}{lccccc}
\hline \multicolumn{5}{c}{ Model } & \multicolumn{5}{c}{ CRM } & & & \\
& Sum of Squares & DF & Mean Square & $F$ & Sig. \\
\hline Regression & 320.380 & 5 & 80.095 & 79.266 & 0.000 \\
Residual & 251.604 & 249 & 1.010 & & \\
Total & 571.984 & 254 & & & \\
& $\mathrm{R}^{2}$ & & & & \\
& 0.560 & & & & \\
\multicolumn{1}{c}{ Model } & Standardised & & & \\
(Constant) & coefficients, Beta & & & & \\
Trust & & -2.121 & 0.035 & & \\
Commitment & 0.148 & 2.130 & 0.034 & & \\
Conflict-handling & 0.347 & 4.699 & 0.000 & & \\
\hline
\end{tabular}

Source: Researcher's construct

\subsubsection{Non-life insurance industry}

TABLE 4: Influence of trust, commitment and conflict-handling on CRM

\begin{tabular}{|c|c|c|c|c|c|}
\hline & & $C R M$ & & & \\
\hline Model & Sum of Squares & $D F$ & Mean Square & $F$ & Sig. \\
\hline Regression & 298.445 & 3 & 80.095 & 79.266 & 0.000 \\
\hline Residual & 221.119 & 397 & 1.010 & & \\
\hline \multirow[t]{3}{*}{ Total } & 519.564 & 400 & & & \\
\hline & $\mathrm{R}^{2}$ & & & & \\
\hline & 0.560 & & & & \\
\hline Model & $\begin{array}{c}\text { Standardised } \\
\text { coefficients, Beta }\end{array}$ & $T$ & Sig. & & \\
\hline (Constant) & & -2.055 & 0.028 & & \\
\hline Trust & 0.092 & 1.869 & 0.315 & & \\
\hline Commitment & -0.243 & -2.533 & 0.026 & & \\
\hline Conflict-handling & 0.523 & 8.014 & 0.017 & & \\
\hline
\end{tabular}

Source: Researcher's construct

In terms of the non-life segment of the insurance industry, TABLE 4 illustrates that conflicthandling exerted a statistically significant positive influence on CRM, while commitment exerted a statistically significant negative influence on CRM. This implies that as commitment increases, 
the need for CRM decreases, i.e. the improved management of customers by a short-term insurance provider will not necessarily result in increased loyalty by the customer. Trust exerted a statistically insignificant influence on CRM. The researcher relied on a $95 \%$ level of confidence, therefore a p-value of less than or equal to 0.05 implied that it is highly unlikely that the results are due to chance only, according to the Independent Sample t-test. This implied that in the case of commitment and conflict-handling, the null hypotheses are rejected and the alternative hypotheses are accepted. In the case of trust, the alternative hypothesis is rejected and the null hypotheses are accepted. The relationship between trust and CRM is insignificant at $p=0.315$, the relationship between commitment and CRM is significant at $p=0.026$, and the relationship between conflict-handling and CRM is significant at $p=0.017$. The Beta values range between 0.243 and 0.523 , with conflict-handling $(0.523)$ having the largest influence on CRM and trust (0.092) having the lowest influence. Commitment has a negative influence on CRM with a value of -0.243 .

Alternative hypotheses HA2b and HA3b and the null hypothesis HOIb are therefore accepted.

\subsection{The influence of CRM on customer loyalty}

Multiple regression analysis was performed to assess the relationship between CRM and customer loyalty. The results are reflected in TABLE 5 and TABLE 6 .

\subsubsection{Life insurance industry}

TABLE 5: Influence of CRM on customer loyalty

\begin{tabular}{|c|c|c|c|c|c|}
\hline \multicolumn{6}{|c|}{ Customer loyalty } \\
\hline Model & Sum of Squares & $D F$ & Mean Square & $F$ & Sig. \\
\hline Regression & 503.073 & 1 & 503.073 & 1019.925 & 0.000 \\
\hline Residual & 124.298 & 253 & 0.493 & & \\
\hline Total & 627.371 & 254 & & & \\
\hline & $\mathrm{R}^{2}$ & & & & \\
\hline & 0.802 & & & & \\
\hline Model & $\begin{array}{c}\text { Standardised } \\
\text { coefficients, } \\
\text { Beta }\end{array}$ & $T$ & Sig. & & \\
\hline (Constant) & & 1.691 & 0.092 & & \\
\hline CRM & 0.895 & 31.936 & 0.000 & & \\
\hline
\end{tabular}

Source: Researcher's construct

In terms of the life insurance market, TABLE 5 indicates that CRM positively influenced customer loyalty. The relationship between CRM and customer loyalty is significant at $p=0.000$. This relationship implied that if the life insurance organisation successfully maintained relationships with its customers, customer loyalty at the organisation will increase. TABLE 5 indicates that the 
CRM multiple regression analysis explained $80.2 \%$ of the variance $\left(R^{2}\right)$ in customer loyalty. In other words, it can be said that $80.2 \%$ of a possible change in the level of customer loyalty in the life insurance organisation is caused by CRM. TABLE 5 further indicates that one unit increase in CRM will increase customer loyalty with $89.5 \%$ when considering Beta. Alternative hypothesis $\mathrm{HA}^{4 a}$ is therefore accepted. The Beta value in TABLE 5 illustrates that CRM has a positive influence on the dependent variable 'customer loyalty', with a value of 0.895 .

\subsubsection{Non-life insurance industry}

\section{TABLE 6 Influence of CRM on customer loyalty}

\begin{tabular}{|c|c|c|c|c|c|}
\hline \multicolumn{6}{|c|}{ Customer loyalty } \\
\hline Model & Sum of Squares & $D F$ & Mean Square & $F$ & Sig. \\
\hline Regression & 496.113 & 4 & 467.116 & 1154.433 & 0.004 \\
\hline Residual & 132.557 & 396 & 0.584 & & \\
\hline Total & 628.673 & 400 & & & \\
\hline & $R^{2}$ & & & & \\
\hline & 0.726 & & & & \\
\hline Model & $\begin{array}{c}\text { Standardised } \\
\text { coefficients, } \\
\text { Beta }\end{array}$ & $T$ & Sig. & & \\
\hline (Constant) & & 1.775 & 0.081 & & \\
\hline CRM & 0.794 & 29.976 & 0.004 & & \\
\hline
\end{tabular}

Source: Researcher's construct

In terms of the non-life insurance market, TABLE 6 illustrates that CRM positively influenced customer loyalty. The relationship between CRM and customer loyalty is significant at $p=0.004$. This relationship implied that if a non-life insurance organisation successfully maintained relationships with its customers, customer loyalty at the organisation will increase. TABLE 6 further indicates that the CRM multiple regression analysis explained $72.6 \%$ of the variance $\left(R^{2}\right)$ in customer loyalty. In other words, it can be said that $72.6 \%$ of a possible change in the level of customer loyalty in the non-life insurance organisation is caused by CRM. Table 6 further indicates that one unit increase in CRM will increase customer loyalty with $79.4 \%$ when considering Beta. Alternative hypothesis $\mathrm{HA}^{4 \mathrm{~b}}$ is therefore accepted. The Beta value in TABLE 6 illustrates that CRM has a positive influence on the dependent variable 'customer loyalty', with a value of 0.794 .

The results of the findings of the empirical investigation are presented in FIGURE 2. 


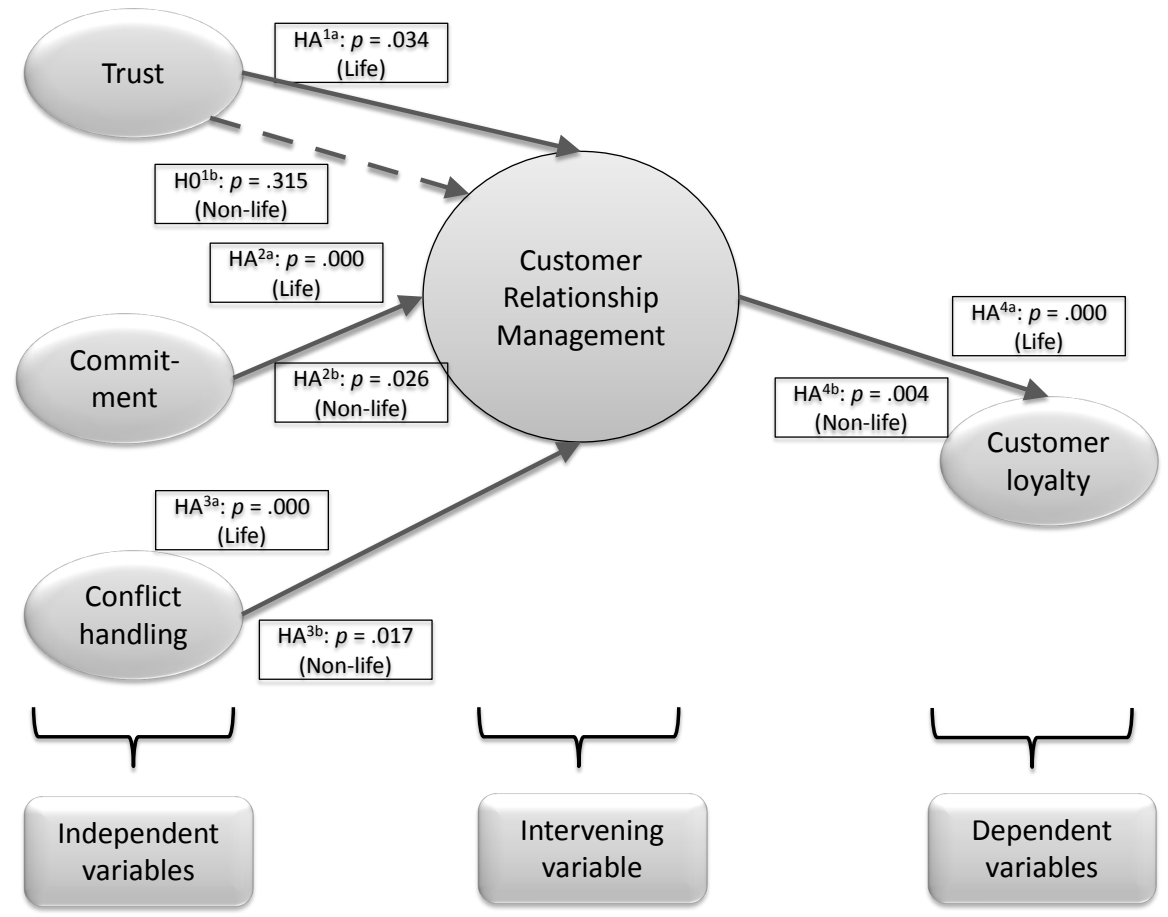

FIGURE 2: Empirical model modified - Life and non-life insurance industry

Source: Researcher's construct

\section{MANAGEMENT IMPLICATIONS AND RECOMMENDATIONS}

\subsection{Trust}

Financial matters are important to people: they want to know that their and their dependants' future is secure should an unplanned event take place that could make them disabled or force their dependants to fulfil financial obligations after their death. Therefore, customers desire to trust life insurance organisations. Customers thus desire these organisations to be trustworthy. This specifically indicates that employees of life insurance organisations with whom customers directly interact should show respect to customers and be honest and truthful in their dealings with customers. Managers at these organisations can increase the organisations' level of CRM if they ensure that the promises made by the life insurance organisations are reliable, that these organisations provide quality service to customers on an ongoing basis, and that they fulfil their obligations to customers. For the level of CRM at life insurance organisations to increase, customers must have confidence in the organisations' service provision. Life insurance organisations must also be willing to be exposed to risks in order to be trustworthy. These organisations can become more trustworthy by giving and keeping promises to customers, showing concern for the security of their transactions, providing quality services, showing respect for customers through front-line staff, and fulfilling obligations. All this will contribute to building confidence in life insurance organisations and the services they offer. Finally, life insurance organisations should also take steps to ensure that their salesforce sells policies 
developed for different target markets only to the identified target market, thus reducing the risk of policies being sold outside the target market and therefore not living up to their promises.

In the case of non-life insurance providers, it is recommended that they place greater emphasis on the need for short-term insurance in order to highlight its importance. This can be done by emphasising the outcome of unforeseen circumstances, and the fact that the outcome is worse if the customer does not have short-term insurance. Non-life insurance providers can also enhance trust by communicating regularly with their customers on aspects such as better deals or better options that will clearly benefit the customer, and by making sure that insurance claims are managed in a professional manner without any problems. If customers are paying a monthly premium, it is expected that they should benefit at a time of need. The level of trust should be assessed on a regular basis in order to determine any changes that need to be made relating to staff and strategies. The staff of the organisation must be trained in keeping the personal information of customers confidential. They may also need training on how to make customers feel that they can trust the organisation, such as reassuring them that their personal details will be kept confidential and their requests will be processed in due time.

\subsection{Commitment}

Commitment is a critical factor in building customer loyalty. Therefore, both life and non-life insurance organisations should accommodate customer needs, and should tailor their products to meet the requirements of their respective customer groups. They should also be flexible in their relationships with customers. Life insurance organisations can identify the needs of different customers and satisfy them through customer segmentation. Financial products can then be developed that address the needs of the target market. The following segmentation criteria may be considered: relationship revenue and relationship cost, relationship volume, relationship profitability, or relationship volume and profitability. By selecting relationship volume and profitability, an organisation can ensure that its actions are directed towards the most profitable customers, in order to increase their commitment and loyalty towards the organisation. An organisation can only fulfil and be flexible to the needs of customers if they understand what customers want. By understanding what customers want, an organisation can create a pull for its services from committed customers. To better understand the segmented customer groups, life insurance organisations must capture information each and every time the customer interacts with the organisation. The interactions can be as a result of the customer entering into a new policy or making an investment, calling the call centre, complaining, visiting the walk-in-centre or just visiting the website of the life insurance organisation. This information can then be used with other information such as demographics and psychographics to better understand customers, and to create products for the individual needs of customers, or to treat customers as individuals.

The non-life insurance industry can encourage commitment by offering incentives such as a noclaims bonus for not claiming over a certain period of time, as well as rewarding customers with lower payments and cash-back bonuses. These insurance providers must ensure that the incentives provided are relevant and appealing to customers. They can do research in order to determine this. Each customer will have different preferences which will provide the organisation with various options to offer. Some may prefer a weekend away, others financial incentives or meal vouchers. These organisations could go as far as linking up with a specific car dealership and providing incentives such as discounts on vehicles, parts or services for 
remaining with the organisation. Non-life insurance providers also segment their customers according to their life-time value as well as profitability. With regard to CRM, organisations should first divide their customers into groups before deciding which customers have greater potential and therefore need increased attention. It may not be viable for a relationship to be built with each customer. The level of commitment of the organisation and the customer should be assessed on a regular basis by means of surveys or questionnaires. If commitment is low, the reason must be determined and corrective actions must be put into place.

\subsection{Conflict-handling}

Customers will be loyal to a life insurance organisation if it handles customer complaints and other conflicts satisfactorily. It is therefore important that effective conflict-resolution mechanisms are not only in place, but are proactive, so as to pre-empt potential sources of conflict and address them before problems manifest. A life insurance organisation should also have an effective customer relations department to ensure that reactive solutions are formulated decisively and in time to resolve problems and protect customers from avoidable losses. A life insurance organisation must be willing to discuss problems with customers openly. The manner in which conflicts are handled by a life insurance organisation will influence customer loyalty directly. The degree to which a life insurance organisation and its customers in the relationship engage in conflict-handling processes will depend on their prior satisfaction with the relationship, the magnitude of the investment in the relationship, and the alternatives that the parties have.

A life insurance organisation should also make it as easy as possible for customers to complain. Written complaints should only be required if deemed necessary for legal reasons. The organisation should inform customers of failures or mistakes, and if the life insurance organisation cannot correct them immediately, they should inform the customer when they will be rectified. A life insurance organisation should compensate customers immediately, and where immediate compensation cannot be given, no unnecessary delays should be allowed. A lost profitable customer has a greater effect on the long-term profitability of a life insurance organisation than overcompensation. The satisfied compensated customer will continue his relationship with the life insurance organisation and will most probably also contribute to favourable word-of-mouth communication. Emotional reactions from customers, such as anxiety and frustration as a result of the service failure or mistake must also be managed, in addition to recovering the failure. An organisation must apologise, but it may not be enough in some situations. Customers must be compensated for losses suffered as a result of a mistake by the organisation.

If an organisation does not handle complaints with urgency and respect, customers will see no reason to trust, commit to, or communicate with the organisation. This emphasises the need for adequate and effective problem-solving. When conflicts are effectively resolved, customers who experience a problem will not hesitate to notify the organisation again before it affects any other customers. Conflict between a customer and an organisation can possibly result in customer loyalty due to the positive handling of a conflict situation.

The non-life insurance industry should make the process of laying a complaint problem-free in order to encourage customers to notify them of problems, as their customers comprise their only source of identifying problems or areas that need improvement. Non-life insurance providers can do this by providing blogs or complaint boards on their website that can be accessed at any time. These organisations must also realise the importance of keeping customers informed 
regarding the progress of the resolving of a conflict or problem. It is the effective resolving of problems that causes the customer to build greater respect for the organisation, and this in turn encourages the customer to be loyal to the organisation. The conflict-handling of the organisation should be assessed on a regular basis by means of surveys or questionnaires. This will enable the organisations to determine if they are resolving conflicts in a satisfactory manner, or if weaknesses need to be brought to their attention. Organisations can also offer online complaint facilities with set standards relating to response time and follow-up. It is imperative to have facilities such as call centres that make it easy for customers to voice their complaints and feel satisfied about doing this and getting conflicts resolved.

\subsection{Relationship between CRM and customer loyalty}

In order to maintain relationships with customers and to retain loyal customers, a life insurance organisation can provide special benefits to loyal customers - for example, lowering policy charges when new policies are entered into, and charging lower administrative fees for managing investments. A life insurance organisation should ensure that CRM, and therefore customer loyalty, increases by delivering high-quality and high-value products and services. Insurance policies and other services provided to customers should therefore deliver on promises made.

Employees should be trained to understand that every single contact with a customer must count. Customers' first impressions are the ones they remember; therefore front-line employees should be equipped to ensure a positive first experience. This is the best way to acquire loyal customers. A life insurance organisation must know its customers. Loyalty schemes equivalent to Discovery's Vitality Programme can be introduced by a life insurance organisation. This loyalty programme will not only contribute to obtaining a larger share of the wallet of the customer, but can also be used to obtain more information about customers. A life insurance organisation must build a system linked to its policy master that will inform management when customers defect. These customers should be contacted immediately and asked why they intend leaving the life insurance organisation, and to determine if anything can be done to rectify the reason why the customer is unhappy. In addition, a life insurance organisation must also deliver excellent customer services. The particular experience a customer has with customer service will influence how the customer feels about the organisation. An organisation should always do the unexpected and that is to treat customers well. Unfortunately, as a result of being accustomed to poor service, most customers today expect to be ignored or mistreated. The organisation can request senior managers to phone customers personally to thank them for their business or provide reasons for a mistake made, and indicate what the life insurance organisation is doing to rectify the mistake. A life insurance organisation should use its customer database to maximise the personalisation of offers to customers. Should a life insurance organisation be able to implement the recommendations, customer loyalty will increase, which will lead to higher profits and will provide a life insurance organisation with a sustainable competitive advantage.

Non-life insurance providers should retain and develop loyal customers by being trustworthy, committed, and lastly by resolving conflicts in a timely and acceptable manner, limiting the problems and disappointment experienced by the customer. This can be achieved by monitoring complaints and communication with customers, as well as conducting regular surveys assessing the level of trust and commitment in order to determine how and if these levels need to be improved. Trust can be obtained by delivering on promises made, which in turn can lead to 
commitment. Commitment can also be achieved through personalising offerings to the individual needs of customers in order to provide them with a reason to be loyal. Non-life insurance providers must therefore ensure that they offer incentives in order to encourage customers to be loyal. These incentives include the "pay-as-you-drive" policy, which is offered by a non-life insurer in South Africa, and is relevant to customers who do not drive a lot and therefore do not warrant an expensive premium. It is the tailoring of offers, such as this, that encourages customers to be loyal. Non-life insurance organisations could also introduce loyalty programmes that track the number of claims made, and decrease the premiums for every year that no claims are made.

\subsection{Relationship between the biographic variables and the intervening variable, CRM, and the dependent variable, customer loyalty}

As there was no empirical evidence to suggest that a relationship exists between biographical variables and the intervening variable CRM and the dependent variable customer loyalty, no specific recommendations can be made in this regard. What is clear from the findings is that all customers, in both the life and non-life insurance market, are of the opinion that trustworthiness, commitment, and conflict-handling are important for the development of a relationship with the insurer.

\section{LIMITATIONS OF THE STUDY AND AREAS FOR FUTURE RESEARCH}

The study focused on only 254 life insurance and 400 non-life insurance customers and can therefore not be seen as representative of all the customers of the insurance industry in South Africa. The study specifically focused on CRM and customer loyalty at the Customer Walk-inCentres at the offices of the life and non-life organisations in the study in Johannesburg, Pretoria, Durban and Cape Town. Therefore the study cannot be seen as representative of the entire insurance industry in the country. As the study focused only on major cities in South Africa, a more inclusive study of all areas in South Africa is therefore recommended. A comparative study with one or more of the other life and non-life insurance organisations in South Africa (not included in the study) can also be considered.

\section{CONCLUSION}

This research succeeded in identifying a list of dimensions that underpin CRM and factors which can predict customer loyalty in the life and non-life insurance industry in South Africa. Managers aiming to build a loyal customer base should concentrate on the issues of trust, commitment and conflict-handling. Strategies to improve the trustworthiness of both a life and non-life organisation's commitment to service, how it obtains information concerning the customers' needs, and how conflicts between customers and the organisation are dealt with during a service failure, should be implemented. The strategies, when implemented, will increase customer loyalty, which in turn will lead to both increased profitability and the sustainability of the organisations in the future. 


\section{LIST OF REFERENCES}

Adoyo, B., Ondoro, C.0., Ojeroa, P.B., Abong'o, B., Aila, F.0., Jeremia, S.N. (2012). The Relationship between Customer Service Quality and Customer Loyalty among Retail Pharmacies in Western Kenya. Business and Management Review, 2(3), pp.11-21.

Alhabeeb, M.J. (2007). On consumer trust and product loyalty. International Journal of Consumer Studies. 31, pp. 609-612.

Amin, G., Almani, M., Pournaserani, A \& Mousavian, S.J. (2011). Relationship Marketing: A new approach to marketing in the third millennium. Australian Journal of Basic and Applied Sciences, 5(5), pp. 787-799.

Angelis, J., Pinheiro de Lima, E. \& Siraliova, J. (2010). Servitised experiences: business and management implications. Vers/o Aktualijos/Current/ssues of Business, 5, pp. 5-21.

Baran, R.J., Galka, R.J. \& Strunk, D.P. (2008). Principles of customer relationship management. Mason: Thomson South-Western.

Benamati, J., Fuller, M.A., Serva, A. \& Baroudi, J. (2009). Clarifying the integration of trust and TAM in $\varepsilon$-commerce environments: implications for systems design and management. IEEE Transactions on Engineering Management.

Botha, G.J. \& Van Rensburg, A.C. (2010). Proposed business process improvement model with integrated customer experience management. South African Journal of Industrial Engineering, 2(1), pp. 45-57.

Bruner, G. C. Hensel, P.J. \& James, K.E. (2005). Marketing scales handbook, 4: Consumer behavior. Chicago: South-Western Educational and Professional.

Caceres, R.C. \& Paparoidamis, N.G. (2007). Service quality, relationship satisfaction, trust, commitment and business-to-business loyalty. European Journal of Marketing, 41(7/8), pp. 836-867.

Chan, K.W. (2004). Examining the antecedents of relationship quality, customer satisfaction and customer loyalty. Unpublished MBA dissertation. Kota Kinabalu: University of Malaysia Sabah.

Churchill, G.A. \& lancobucci, D. (2005). Marketing Research Methodological Foundations, $9^{\text {th }}$ edition. Mason: South-Western Thomson.

Datamontior. 2011. Country analysis report, South Africa. n.p.: Datamonitor.

Du Plessis, L. (2010). Customer Relationship Management and its influence on customer loyalty at Liberty Life in South Africa. Unpublished Master's dissertation. Johannesburg: University of Johannesburg.

Du Plessis, P.J., Jooste, C.J. \& Strydom, J.W. (2005). Applied strategic marketing, $2^{\text {nd }}$ edition. Sandton: Heinemann.

Dwyer, F.R., Schurr, P.H. \& Oh, S. (1987). Developing buyer-seller relationships, Journal of Marketing, 51(2), pp. 11-27.

Halimi, A.B., Chavosh, A. \& Choshali, S.H. (2011). The Influence of Relationship Marketing Tactics on Customers' Loyalty in B2C Relationship - the Role of Communication and Personalization. European Journal of Economics, Finance and Administrative Sciences, 31, pp. 49-56.

Helkkula, A. \& Kelleher, C. (2010). Circularity of customer service experience and customer perceived value. Journal of Customer Behaviour, 9(1), pp. 37-53. 
Hugo, F. \& Zondagh, P. (2007) Measuring the insurance gap by reference to the financial impact on South African households of the death or disability of an earner. Cape Town: Life Offices Association. Jumaev, M., Kumar, D. \& Hanaysha, J.R.M. (2012). Impact of Relationship Marketing on customer loyalty in the banking sector. Far East Journal of Psychology and Business, 6(3), pp. 36-55.

Kaur, G., Sharma, R.D. \& Mahajan, N. (2012). Exploring customer switching intentions through relationship marketing paradigm. International Journal of Bank Marketing, 30(4), pp. $280-302$.

Kim, K.H., Kim, K.S., Kim, D.Y., Kim, J.H. \& Kang, S.H. (2008). Brand equity in hospital marketing. Journal of Organisation Research, Vol. 61, pp. 75-82.

Kotler, P. \& Keller, K.L. (2006). Marketing Management, $12^{\text {th }}$ edition. New Jersey: Pearson Prentice Hall.

Krasnikov, A., Jayachandran, S. \& Kumar, V. (2009). The impact of Customer Relationship Management implementation on cost and profit efficiencies: Evidence from the U.S. commercial banking industry. Journal of Marketing, 73, pp. 61-76.

Leverin, A. \& Liljander, V. (2006). Does relationship marketing improve customer relationship satisfaction and loyalty? International Journal of Bank Marketing, 24(4), pp. 232-251.

Lian, C., Chen, H. \& Wang, W. (2008). Does online relationship marketing enhance customer retention and cross-buying? The Service Industries Journal, 28(6), pp. 769-787.

Life Offices Association. (2011). Half-yearly statistics - circular 74/2010. Cape Town: Life Offices Association.

Madiba, G. (2009). The influence of the elements of the extended marketing mix on consumers' intention to purchase at a fast-food retail chain in Johannesburg. Unpublished master dissertation. Johannesburg: University of Johannesburg.

Malhotra, N.K. (2007). Marketing research an applied orientation. New Jersey: Pearson Prentice Hall.

Moorman, C., Deshpandé, R. \& Zaltman, G. (1993). Relationships between Providers and Users of Market Research: The Role of Personal Trust. Marketing Science Institute, Cambridge, MA.

Morgan, R.M. \& Hunt, S.D. (1994). The Commitment-Trust Theory of Relationship Marketing. Journal of Marketing 58, pp.20-38, July.

Mousavian, S.J. , Moaf, S.M., Jelodarloo, S.N.A., Pournemat, M., Tajalli, M., Damirchi, F.G. \& Seighalani, F.Z. (2011). Comparative Study of Relationship Marketing In Public and Private Banks. Interdisciplinary Journal of Contemporary Research in Business, 3(8), pp. 508-514.

Ndubisi, N.0. (2004). Understanding the salience of cultural dimensions on relationship marketing, its underpinnings and aftermaths. Cross Cultural Management, 11(3), pp. 70-89.

Ndubisi, N.O. (2007). Relationship marketing and customer loyalty. Marketing Intelligence \& Planning, 25(1), pp. 98-106.

Ndubisi, N.0. \& Wah, C.K. (2005). Factorial and discriminant analyses of the underpinnings of relationship marketing and customer satisfaction. International Journal of Bank Marketing, 23(7), pp. 542-557.

Nguyen, B. \& Mutum, D.S. (2012). A review of Customer Relationship Management: successes, advances, pitfalls and futures, Business Process Management Journal, 18(3), pp. 400-419.

Payne, A. \& Frow, P. (2005). A strategic framework for Customer Relationship Management. Journal of Marketing, 69, pp. 167-176. 
Read, B. (2009). Top Tips To Build and Keep Customer Loyalty With CRM. Customer Inter@ction Solutions, 27(9), pp. 26-28.

Sauers, A.C. (2008). Effective customer relationship management. New York: Cambria Press.

Strachan, L. (2010). Investigating the influence of Customer Relationship Management and its influence on customer loyalty at selected short term insurance providers in Gauteng. Unpublished Honours dissertation. Johannesburg: University of Johannesburg.

Theron, E. \& Terblanche. N. (2009). Dimensions of relationship marketing in business-to-business financial services. International Journal of Market Research, 52(3), pp. 383-402.

Tynan, C. \& McKechnie, S. (2009). Experience marketing: a review and reassessment. Journal of Marketing Management, 25(5), pp. 501-517.

West, S.G., Finch, J.F. \& Curran, P.J. (1995). Chapter 4: Structural equation models with nonnormal variables: problems and remedies In HOYLE RH (ed). 56-75. Newbury Park, California: Sage.

Wong, A. \& Sohal, A. (2002). An examination of the relationship between trust, commitment and relationship quality. International Journal of Retail \& Distribution Management, 30(1), pp. 34-50. 